\title{
Advertising in Communication of the Catholic Church. The Case of Poland
}

\author{
Krzysztof Stępniak \\ ORCID: 0000-0001-9716-8835 \\ CARDINAL STEFAN WYSZYŃSKI UNIVERSITY IN WARSAW, POLAND
}

\begin{abstract}
Religious advertising as a kind of religious persuasive communication based on the element of the sacred is a Polish phenomenon. The article presents studies on religious advertising, its definition and typology and reception by select social groups. This kind of advertising confirms not only Hjelm's concept of the visibility of religion, as it exists in both the media and public sphere, but also David Herbert's concept of republicisation. In a country without a clear division between State and the Church, despite a well-researched decline in traditional religiosity, religion is visible in social media and facilitates development of human relationships, both online and offline. Commercial media, including the Catholic ones, seem to be perfectly subjugated to the logic of media, which supports Stig Hjarvard's process of mediatization of religion.
\end{abstract}

KEYWORDS: advertising, communication, Catholic Church, Poland, religious advertising, mediatization of religion.

\section{INTRODUCTION}

The contemporary world is characterised by the processes of secularization (and its opposite) (Hjelm, 2012; Dobbelaere, 2002) and mediatization (Hepp, 2019), which contain mediations of all forms of social life, including also the religious (Lövheim, 2011). In the 2010s, religious institutions, such as the Catholic Church, face new challenges and problems with communication between the sacred and community (Evolvi, 2019; Kołodziejska, 2018).

In mediation of religious messages, religious advertising may have important, albeit still undervalued a roles as a both a message containing elements of the sacred and the medium of a religious message hitherto little used by religious institutions. The message is addressed to recipients of contemporary media, as well as social media. The aim of the present text is to analyse religious advertising not only in the light of the processes of secularization and mediatization of religion but also the role which this kind of advertising may play in the 
communication of the Church in Poland. The study is based on topical research literature, studies concerning mediatization of religion in the Central Europe and own research on the reception of religious advertising in Poland carried out at the University of Warsaw during February and March 2016.

\section{RELIGIOSITY OF THE POLES AND SECULARIZATION AND MEDIATIZATION OF RELIGION}

The majority of Polish society belongs to the Catholic Church, which does not have any significant religious competition other than the Orthodox Church in the the eastern areas of the country. The Catholic Church has since 1990, and the period of systemic transition, been carrying out religious education in all types of schools (primary and secondary), still cultivating vividly the teachings of the Pope from Poland, John Paul II. Recently, though, the image of the Catholic Church has suffered significantly. According to sociological studies, the role of the Church as an institution deserving of social trust has been weakening; the authority of her representatives has been declining (Kościół w Polsce. Raport, 2018).

Sociological studies carried out 25-30 years after the political transformation indicate a slow but systematic decrease in the percentage of declarations of identification with the faith of the Catholic Church and the number of Poles who regularly practice (worship) (Kościół w Polsce. Raport, 2018; Mariański, 2016; Pawłowska, 2015; Religijność Polaków..., 2020) - see table 1. The obtained data seem to confirm the occurrence of the phenomenon of secularization, which with some delay - in comparison with Western European countries - affected Polish society, which for a long time maintained a relatively high level of religiosity (Mariański 2009, 2010).

Table 1. Declaration of faith (belonging to a religious denomination) by Poles in the years 2005-2020 (in percent)

\begin{tabular}{c|c|c|c}
\hline Year & $\begin{array}{c}\text { People who identify } \\
\text { with faith }\end{array}$ & $\begin{array}{c}\text { People declaring belonging } \\
\text { to the Catholic Church }\end{array}$ & $\begin{array}{c}\text { People declaring themselves } \\
\text { as unbelievers and } \\
\text { rather unbelievers }\end{array}$ \\
\hline 2005 & 96 & 94.6 & 4 \\
\hline 2012 & 94 & 93.1 & 7 \\
\hline 2015 & 94.2 & 92.8 & 8 \\
\hline 2018 & 93.5 & 91.9 & No data \\
\hline 2020 & 91 & No data & 8 \\
\hline
\end{tabular}

Source: Author's own summary based on: Kościół w Polsce. Raport, 2018; Życie religijne..., 2018; Religijność Polaków..., 2020 
As we read in the report of the Catholic Information Agency,

the percentage of people for whom faith is an important point of reference in life remains constant, whereas the number of people who partially or entirely leave the faith is increasing. [...] the number of the religiously "mild« is decreasing - the religiously »cold « are increasing, whereas the number of »hot ones« stays the same. (Kościót w Polsce. Raport, 2018, p. 5).

In the years 1991-2015, the number of people who were indecisive, albeit "attached to religious traditions" doubled (from 6.0 to 12.0\%), also the number of the indifferent increase (from 2.4 to 5.3\%). Indicators illustrating Poles' daily religious practices show that in 1991-2020 the number of people practicing regularly decreased from 52.4 to $47 \%$ ). In turn, the number of people practicing irregularly increased (from $33-34 \%$ in $1997-2007$ to $38 \%$ in 2020). The percentage of people not practicing in 2020 amounted to $15 \%$, i.e. $6 \%$ more than 20 years ago (Religijność Polaków..., 2020, p. 2). During that period, also the number of people who prayed everyday declined (from 62 to 53\%), while 7\% did not pray at all (in 1991 - 2\%) (Kościót w Polsce. Raport, 2018, p. 5).

The lowest percentage share of the faithful is observed in the age group 25-34 years (74\%) and 16-24 years (75\%), among residents of cities with over half a million residents (in $2015-83.5 \%$, while in rural areas - 96.3\%), as well as among the best educated persons (Kościół w Polsce. Raport, 2018, p. 5).

Paradoxically, the surveys carried out by the Pew Research Center in 34 European countries in 2017, indicate that young people from Middle and Eastern Europe, in respect to many issues important for the Catholic Church (e.g. abortion, homosexual marriages, migration) are more conservative than both the elderly, as well the young citizens of the Western Europe (Pew Research Center, 2018).

Currently, in Poland, there are almost 33 million baptized people, albeit only $75 \%$ of them takes the sacrament of confirmation (Rocznik Statystyczny Rzeczypospolitej Polskiej, 2018, p. 196; Annuarium Statisticum Ecclesiae in Polonia, 2018, p. 4). According to Mariański, religious practices comprise an important indicator of religiosity in both dimensions: the individual and the social. Abandoning religious practices always means some kind of a signal of changes in traditional religiosity. Furthermore, as Mariański stresses, in secularized countries alongside the absence from religious practices, a relatively high level of belief in God is maintained. The researcher stresses that

in Poland diminishing religious practices indicate a loss of respect for the institution of Church, or even weakening of religious beliefs, albeit not all people who stop going to church may be described as "unbelievers". Some of them represent private religiosity, i.e. for various reasons they do not think 
that they have to express their faith in God through active participation in a religious cult (Mariański, 2010, p. 57).

Without a detailed analysis of its various conceptions and perceptions, secularization assumed the disappearance of religion in modern society. However, according to many researchers studying religiosity in the Central Europe, secularization in Poland neither meant nor means disappearance of religion or a huge drop in religious practices, or separation of the Church from the State, as Poland is a country with a uniform religious structure (Borowik, Dyczewska \& Litak, 2012), where the total separation of Church and State did not happen (Guzek, 2019).

In the context of significant concepts of secularization, researchers such as José Casanova (1994) or Charles Taylor (2007) perceive the mechanism of secularization in a slightly different way and they seem to be closer to the case of Poland. Casanova's concept of secularization is based on three dimensions. The first is the progressive loss of beliefs and the decline of religious practices in modern societies. The second refers to the privatization of religion, while the third assumes the emancipation of secular social spheres, meaning their differentiation from religious institutions. Then, Taylor (2007), Robert N. Bellah (2007) and other researchers specify three dimensions of secularization. Taylor's Secularity I level concerns the freedom from religious norm and the authority of religious institutions in such spheres of social life as law, economics, bureaucracy and politics. In Secularity level II, Bellah suggests rejection of religious practices at the individual level, while in level III there is the phenomenon of individualization of religious practices and faith. Taylor's approach is broader than Casanova's one and more adequate to the non-Western context, which is presented in the studies of Mirjam Künkler, John Madeley and Shylashri Shankar (2018) and Guzek (2019). According to Guzek, the Western model cannot be transferred as a general model to the Central Europe countries. Katarzyna Zielińska (2009), describing secularization in Poland, underlines that despite links between the State and Church, we may - applying Taylor's three dimensions of secularization. In Secularity I level, there is the separation of religion and state in such areas of social life as politics, law, economics. In Secularity II level, religious practices at the individual level - especially among young people - have declined, which recent studies on religiosity in Poland carried out by the Public Opinion Research Center (CBOS) have confirmed (Religijność Polaków..., 2020). Religiosity in the country is slowly being privatized, while the incomplete consensus regarding faith is increasing (Borowik, 2010). Taylor's Secularity III level is not reflected in the Polish society, because the dominating narrative proves that Catholic identity is still intertwined with Polish identity (Guzek, 2019). 
Recent years have shown not only a lack of erosion of all things religious, but also even a growth in religious pluralism caused by some opposition to secularization, which Berger (2011) calls desecularization. Catholicism has not disappeared, and it is not as Luckmann (1967) suggests, an invisible religion. Despite modernism not having caused the disappearance of religion, it did cause religion to change. Religion does not re-enter the public sphere, because it never left (Beckford, 2012). Religion instead achieved a new heightened visibility in public life.

The concept of desecularization, although rather problematic and unacceptable by all researchers, seems to fit a description of religiosity in the Central European countries, including Poland. During the period of desecularization, religion and institutional Church are becoming increasingly more visible. This, in turn, is an exemplification of desecularization, which Titus Hjelm (2014) understood as the visibility of religion or an example of David Herbert's (2015) religious publicalization, which means increasing the visibility of religion in the public sphere. Herbert connects it with specific activities of religious and political actors. Most of all, the functioning of religious institutions on the commercial media market is conducted through intensified involvement of representatives of religion.

The visibility of religion is connected with the development and universality of media and their convergence. Religious contents are not only passed on by churches, but also via media (mediation of religion). Media are becoming the carriers of religious contents and to an increasingly greater extent are used by church institutions, which the Church calls the "modern Areopagus". Another phenomenon is mediatization of religion. In the mediatized world, where media play the key and superior role, the process of mediatization of all forms of social life, including religion has taken place (Hjarvard, 2012; Lövheim, 2012). The concept of mediatization of religion is taken from Stig Hjarvard (2008). Mediatization is the processes in the course of which religious ideas and practices become significantly dependent on media. Simultaneously, Hjarvard (2014) takes the position that mediatization secularizes religion. Mediatization of religion in Poland has its own specifics. Primarily, because - as I have already mentioned - it is difficult to talk in Poland about the secularization of both political and religious life, as occurs in Western countries. Religion has not disappeared from public life. Secondly, in the years after the systemic transition, successive governments of Poland made the point of maintaining appropriate good relations with the Catholic Church, which had participated in the downfall of communism. Thirdly, in both public and commercial media, there is a space managed by channels of religious contents, which forced religious broadcasters and religious actors to adapt to the logic of the media. According to some research in Europe, modernism did not result in the marginalization of religion (Davie, 2007). 
Nowadays, in global environment of social media and uniform usage of smartphones all permanently connected to the net, many people are already unable to experience their faith only offline. As Sherry Turkle in her book Life on the Screen (1995) observes, already in the 1990s, digital media allowed internet users to shape and express their identity. According to the research, religion in the internet and experiencing faith, as well as affirmation of own religiosity have a significant impact on contemporary religiosity, also outside the internet. Hoover, Clark and Rainie (2004, p. 20) claim the internet caused that its users to become more autonomic and independent from formal authorities and church institutions in faith related matters. Hitherto, surveys seem to confirm that the use of the internet for formulating religious identity and expressing religiosity through digital media is becoming mostly individual and personal, as well as independent from formal groups. This individualization of religion impacts upon one of the basic functions of religion, which is connecting people, i.e. community-ness.

In her studies, Kołodziejska (2018) observes that in Poland, online and offline communities have many common features: they are created for multiple purposes, they connect people with similar interests and/or values, the commitment of their members may differ and change, they may also have an extended hierarchic structure. Thus, online relationships are equally valid as those established offline, and usually their objective is not creating opposition or an alternative to offline communities (Etzioni, 2003). Wellman and Gulia (1999) argue most contemporary (offline) relationships are based on intermediation of media. By contrast, internet users who enter interactions with others bring their entire baggage of obtained experiences, beliefs and values, as well as various aspects of their identity (e.g. related to gender, education, religious denomination, etc.), similar to what takes place in terrestrial communities (Wellman \& Gulia, 1999; Kubczak, 2005; Szpunar, 2005). Therefore, it may be concluded that the research of the authors such as Zielińska, Borowik or Kołodziejska and Guzek support Hjelm's concept of the visibility of religion in the Polish reality. This is because religion is visible in both the internet as well as in the reality of public life and despite some decline in the level of religious practices (particularly in the large urban centres) plays an important role in societal life. 


\section{THE FORMS OF THE CATHOLIC CHURCH COMMUNICATION WITH THE FAITHFUL}

In the face of secularization and mediatization of religion in Western Europe and in the post-communist countries of Central Europe, the Catholic Church was confronted with the necessity of returning to Christian basics, religious values and practices in the countries of Western Europe. This strategy was called the "new evangelization". The aspect that underlined its implementation was that the "traditional" forms of the Church communication, such as homilies, pastoral letters, announcements or communiques were no longer sufficient. Similar to liturgical rites, these traditional forms are being increasingly mediatized. An example of the use of media in the everyday life of local churches are the surveys of Zbigniew Chmielewski and Paweł Kuca, carried out at the start of 2012 and 2013 in the parishes of the Rzeszów Diocese. The respondents were asked which of the Catholic Church's information policy and communicating tools they used. The most popular were the traditional forms of parochial announcements during holy mass and the noticeboard at the church. However, the third most preferred source of information was a parish's website. Only few indicated advertising banners, text messages or email contacts (Chmielewski \& Kuca, $2013,2014 / 2015)$. The CBOS poll (2016) indicates that $15 \%$ of internet users access religious portals - mainly aged $45-54$ years (21\%) and aged 25-34 years (17\%). Parishioners who were the least likely to use the internet were rural residents. Nevertheless, $51 \%$ of visitors to religious websites declared themselves as deeply believing, while $45 \%$ were motivated by their urge to supplement their religious activity carried out offline (e.g. prayers, participation in services). Internet portals are mainly a source of information about contemporary affairs in a parish (46\%) and the Catholic Church (36\%) and religious texts (e.g. Bible online) - 31\% (Korzystanie z religijnych stron..., 2016).

Over half of the Church's parishes (55.1\%) use their own website to communicate with the faithful, some have started to use social media (16.5\%), while close to a third (32.4\%) have maintained their reliance on information on paper to communicate with the faithful (Annuarium Statisticum Ecclesiae in Polonia, 2018, pp. 43-53. In 2011, 2049 parishes (about 20\%) issued parochial magazines (Kościół katolicki w Polsce..., 2014, pp. 60, 257). Information activities of the Church have increasingly involved digital media. 


\section{ADVERTISING IN THE CATHOLIC CHURCH}

For a few years the Catholic Church in Poland has been taking advantage of advertising as "the one of the most suggestive means of expression used by mass media" (Baczyński, 2001).

Within the public sphere, advertising with references to religion, using religious motifs, occurs more frequently, both in the offline and online forms. However, there is still a cautionary attitude, even distrust, towards advertising as a tool used in communication with the audience. It is probably because advertising is associated with consumption and commercialism, many theologians oppose its usage in pastoral ministry or the mission of spreading the Gospel in the Church, believing that neither God nor the Church require advertising.

The distribution channels of such kind of advertising are neither very well recognised nor atypical. It is difficult to study religious advertising applying the same methods as those used in studies on corporate advertisements and their effectiveness. Thus, any calculation of GRP (the power of an advertising campaign) or its impression and correlation with the effectiveness of reaching the audience, and even its influence, may be biased with a high cognitive error. In scholarly literature, advertising applied by the Church is usually defined as advertising of religious content, advertising of religious character, and in its broadest meaning, as a type of social advertising (Stępniak, 2017a). This deficiency of consensus is caused by the lack of an unequivocal definition of religious advertising rooted in the communication and media sciences. Some attempts at describing religious advertising were deprived of this narrow definition, and consequently they focused on the distribution channels and relation to the sacred (Guzek, 2013) or a classification according to contents (Percy, 2000). Moreover, they interchangeably used such notions as religious advertising, church advertising or Christian advertising (Guzek, 2013, Percy, 2000). The attempt at defining religious advertising in the context of religious marketing (Szpunar, 2010) seems to be insufficiently precise, as it focuses only on the sole purpose of drawing attention to spiritual issues, ignoring such important features as a persuasive function of the sacred in this kind of advertising.

\section{RELIGIOUS ADVERTISING}

Assuming that religious advertising is a separate type of advertising, and the science lacks an accurate definition exhausting its constitutive features, I have attempted to investigate the phenomenon of religious advertising in Poland and to define and typologize it (Stępniak, 2017a). 
Four selected focus groups participated in the 2016 study of the phenomenon of religious advertising, carried in the Laboratory of Media Studies of the University of Warsaw (Group 1 "Experts", Group II "Unbelievers", Group III "the Clergy", Group IV "Believers"). Each focus group consisted of 8-12 people.

The study allowed religious advertising as a persuasive message of a religious character and containing an element of the sacred. The aim of the message is to convey information and promotion of faith, values, ideas and services of a religious character, as well as shaping attitudes and opinions in line with the teaching of Catholic Church (Stępniak, 2017a, p. 177). Such advertising will appeal to the recipient's most "spiritual" needs, hence the element of the sacred in advertising, which strengthens or accentuates the spiritual character of advertising. Even though, the scheme based on "need" and "promise" appears, similar to advertising, it is still a kind of non-commercial advertising. However, it is not a kind of social advertising in a general meaning, as its objective is not instilling any change in attitude according to socially desired expectations. The sacred seems to be the necessary and indispensable element or component of this advertising; without this element religious advertising would not differ from other types of advertising and it would be difficult to describe it as religious one (more on the subject see: Stępniak 2017b, 2018).

For the needs of the research project, I used categories useful in describing religious advertising in the form of 10 operationalized detailed research questions, which were applied to all four focus groups: Where does a theoretical and perceived by recipients boundary defining the range of the notion of "religious advertising" run? What are characteristic features of religious advertising? What is its relation to commercial, social and other types of advertising? How are religious advertising and religious marketing received by different groups? Is it an action perceived as appropriate from the point of view of the mission and objectives of the Church and is it effective? How are the objectives of religious advertising understood? How is the sacred presented in religious advertising? Where is the border between the sacred and the profane set? Which correlates at the communication level influence the effectiveness of religious advertising? How does the presentation context influence the reception of religious advertising?

The model of description of the advertising influence (model AIDCAS) with some modifications was applied in the survey. Modifications seemed necessary due to the spiritual dimension of this type of advertising. That is why there are spiritual needs and not purely consumer needs, and in benefits, apart from purely personal, there are also social (community) and ethical benefits. The AIDCAS applied to the survey on religious advertising embraced the questions: What draws attention in religious advertising, what is exceptional, atypical, striking? What stirs interest and prompts to watch the entire advertisement? What kind of involvement does the advertisement prompt? Which needs does advertising 
refer to? How does the advertisement argument the advantages of action? How does the advertisement increase satisfaction after undertaken action? What benefits does it provide at the social, ethical and personal level?

This model illustrates and explains the psychology of advertising, because it contains an element of persuasion, which seems to be particularly important in religious advertising. I used it to analyze individual advertisements presented to all four focus groups.

The advertisements that appeared in Poland in recent years were used in the research. They were selected and chosen within the scope of the preliminary survey and presented to all the focus groups. Among them were such religious advertisements, as: "Marital repair", “The crusaders", "The world needs heroes" (dynamic advertisements), and "Decalogue", "Canonization", "Your candidate" (static advertisement). The titles of advertisements were either given by their authors or appointed during the research. All the advertisements selected for the study are available online.

The course of discussion in particular groups and obtained answers allow generalization of the opinions concerning the presented religious advertisements expressed in particular focus groups and indication of both mutual as well as different assessments, and also drawing conclusions allowing defining the objectives of advertising as a mean of communication and its classification according to its content and recipient.

\section{GROUP 1 - "EXPERTS"}

The group consisted of media specialists, members of staff of advertising agencies, representatives of religious organisations ordering such types of advertisements. The group of "Experts" generally expressed a positive opinion regarding religious advertising, with a reservation that implementation of spiritual and evangelizing goals through advertising was rather doubtful. Some experts also pointed out the significant role of religious advertising in the public discourse, as one of important voices on the market of ideas and a significant way of shaping significantly the image of the Church. Social media achieved such significance that many people view them as the main informative and formative tool, the guidance and inspiration in individual, family and social behaviours. Thus, it is difficult to agree with the voices of "Experts" stating that religious advertising cannot be used as a tool in the deed of evangelization or a means for promoting spiritual values. The fact that they placed advertising in a wide spectrum of communicative and promotional activities of the Church indicates its necessity and irreplaceability in modern communication of church organizations. Advertising is a tool for communication between the sender and the receiver, and is also a part of various promotional activities, similar to public relations. 


\section{GROUP 2 - "UNBELIEVERS"}

The group of "Unbelievers" included people claiming that they did not belong to any Church. The members of this group consented to religious advertising as a form of communication required by contemporary socio-medial environment where both religion and the Church function. It is worth pointing out here, that Unbelievers did not have such doubts as were raised in the group of "Experts" that religious advertising may target the freedom of conviction, free choice of religious denomination, or even interfere in the public space.

At the same time, unbelievers argued about the key role of religious advertising in the function of transforming the image of the Church. Evident here was the opinion that badly designed advertising of this type may strengthen the impression of the Church as an old-fashioned and excessively conservative institution. Image-related advertising of the Church as an institution should be, this focus group argued, modern and attractive, as there often lingers a mistaken notion in society of the Church as a fossilized institution positioned in some opposition to the contemporary world. Also, the group pointed out religious advertising was an effective medium of communication presenting activities and projects carried out by the Church and religious institutions and is an effective medium of true evangelization and stimulation to spiritual reflection.

\section{GROUP 3 - "THE CLERGY"}

The majority of "the Clergy" group agreed on the idea and need for using religious advertising in contacting the surrounding world. Albeit, there were mostly lone voices explaining when and in which situations it should be used.

A few participants noticed the necessity to make a distinction between the used by the Church advertising of evangelizing and informative character and commercial advertising mixing association with traditional marketing. The group felt thorough consideration was necessary when choosing the medium for this advertising and defining its target.

The participants connected the general need for religious advertising with generational and technical changes, to which the Church must adjust her communication. Currently, we live in the world of visual imagery, in iconosphere, hence the huge power of visual elements, also in advertising. In the course of the discussion, this group increasingly agreed with the notion the Church should advertise what she proposes in her teachings, both to the faithful, the seekers the religiously indifferent, albeit as a way of ensuring the dignity of this advertisement exposition.

The group also voiced an opinion that religious advertising, and in wider sense, promotion carried out by the Church, should be implemented through specialized, professional institutions, not belonging to the main structures of the Church (foundations, associations). 


\section{GROUP 4 - "BELIEVERS"}

The group of "Believers" consisted of the people who were associated with the Catholic Church. The predominant view in this group was that the Church needs advertising, particularly in the situation of growing competition on the "markets of ideas", as well as confrontation with the aggressive promotion of other religious denominations and philosophies of life. Advertising of the Catholic Church should be, they argued, primarily ethical, but also implemented in a professional way by specialists. Also, the point was raised on the necessity for reflection upon the usage of advertising and the conclusion of the need for both dignified attitude and behaviour. Catholics and representatives of clergy in direct contact with the public bear more significance than typical marketing communication and promotion techniques.

Religious advertising is necessary as well as appropriate and there is nothing demoralising. Certainly, it will not replace personal contact with God, will not replace the testimony which plays a significant role in evangelization or the teachings of the Church, but it may be a good tool in her evangelizing mission. The group emphasized that the testimony of Catholics, either laymen or clergy, falls rather within the scope of the Church PR, which - and I underline it again - similar to religious advertising belongs among the promotional activities of the Church.

\section{THE TYPOLOGY OF RELIGIOUS ADVERTISING}

On the basis of statements made by the focus groups, and also accepting the rightness of the Philip Kotler's (2005) allegation that the advertising objectives may be divided depending whether they are to inform, convince, remind or strengthen, the objectives of religious advertising include:

1. Enlightening the recipients about their spiritual needs and stimulating their desire to satisfy these needs;

2. Presenting the attractiveness of a given religion, in this case Christianity and thus the universalism of Christ's teachings;

3. Creating preferences and providing rational arguments supporting the choice of a given religion or church. Rational arguments beside emotional ones are included in advertising messages, although they require skills to insert them and to perceive them;

4. Shaping a positive vision of the advertisements' sender, namely the Catholic Church - with her history, great figures of the saints, charismatic personalities;

5. Encouraging a particular action in accordance with the objective of the advertising message, explaining intentions of its creators-senders, taking advantage of the ministry, in this case pastoral ministry, sacraments, 
religious retreats, etc., and hence some consumption of the spirit (for more on the subject see Stępniak, 2017a, pp. 41-42; Kotler, 2005, p. 601).

Regarding religious advertising of the Catholic Church in respect to the message content and its audience, it may be divided into four types of religious advertising: (i) kerygmatic/evangelising advertising - its content is kerygma, i.e. the truth about Salvation; a clear distinction between kerygmatic and evangelising advertising is difficult for an average recipient of advertising to understand; (ii) pastoral advertising - its content comprises all pastoral initiatives, while its audience belongs to the community of the faithful; (iii) vocation advertising (recruiting) - encouraging to choose the priesthood, monastic or missionary way; usually it is advertising for a theological seminar or monastery; (iv) charity advertising (fundraising) - obtaining financial means for the Church's activities, addressed to everyone.

As regards the sender, religious advertising is a kind of Church advertising, which includes religious advertising. Among Church advertisements there is also commercial advertising which does not have to have anything in common with the spiritual needs of the recipients and the element of the sacred is not necessary there. Church advertisements, i.e. those commissioned or prepared by the Church, embrace a wide content-related range, some of them comprise religious advertisements, while the objective of others is a product or service which can be bought.

\section{CONCLUSIONS}

The understanding of religious advertising as the modern medium of information and religious content refers in various aspects to the current establishments within the scope of mediatization of religion in Poland. First, religious advertising clearly accentuates the key important factor in religion, i.e. the sacred. The sacred in this kind of advertising has a close referential link with religion and evidently indicates what is transcendent and sacred. It has nothing in common with religious elements (codes, signs, symbols, figures) used in other types of advertising in order to draw attention, e.g. shockvertising (Stępniak, 2018). Therefore, religious advertising, seemingly conducive to mediatization, stands in opposition to secularization, which is crucial to the whole process (Hjarvard, 2014). Hence, religious advertising as the element of de-secularization cannot provide a separate argument supporting the growth of religion in the public sphere but is rather a symptom of an attempt at maintaining its role. Indeed, religious advertising may be conveyed by any carriers of information, and in reality, may be mostly found on the internet or social media. Some kinds are used by religious actors or religious authorities in their websites, blogs 
or vlogs. Also, religious institutions, particularly religious orders, reach for this type of message in order to encourage the audience's participation in religious retreats, open days or meetings (pastoral advertising), as well as encouraging the choice of the monastic way (vocation advertising). Such advertising is also a matter of importance in religion, i.e. developing human relationships, some kind of community-ness.

Secondly, religious advertising as a persuasive message present in the public sphere, including the element of the sacred, falls in line with what Hjelm (2014) describes as the intensified visibility of religion. In a country without any social division between public authorities and the Church, there is evident place for the sacred in the public sphere, although it sometimes stirs controversies and opposition in secular communities. The sphere of the sacred is noticed due to various religious and state celebrations and functions. Surveys show that this type of advertising also provides some counterbalance to anti-religious or atheistic advertisements appearing in the public sphere. Therefore, religious advertising may serve as the medium of pluralism in the public discourse; in such context it proves the thesis of the republication of religion.

Among the study's strong points, the members of the focus groups emphasize that such advertising refers to everyday life. Increasingly, internet based commercials feature political actors or celebrities (sportspersons, actors, winners of popular television shows) openly speaking about their faith and calling for participation in religious events. Without a shadow of doubt, such visible religion in the public sphere in Poland is well served by religious advertising.

\section{REFERENCES}

Annuarium Statisticum Ecclesiae in Polonia (2018). Warszawa: Instytut Statystyki Kościoła Katolickiego SAC. Retrieved March 4, 2019 from: http://n-1-13.dcs.redcdn.pl/file/o2/tvn/web-content/m/p1/f/ cd14821dab219ea06e2fd1a2df2e3582/f861e5e4-060d-400c-81a3-85faa18ac896.pdf.

Baczyński A. (2001). Ewangelizacja, media i reklama [Evangelization, media and advertising]. Anamnesis, 24(1), 63-70. Retrieved March 4, 2019 from: https://www.nowaewangelizacja.pl/plik/6/ ewangelizacja-i-reklamapdf.

Beckford, J. A. (2012). SSSR presidential address: Public religions and the postsecular. Critical reflections. Journal for the Scientific Study of Religion, 51(1), 1-19.

Bellah, R. N. (2007). After Durkheim. Retrieved January 24, 2019 from: https://tif.ssrc.org/2007/11/23/ after-durkheim/.

Berger, P. L. (2011). Adventures of an accidental sociologist: How to explain the world without becoming a bore. Amherst, N.Y.: Prometheus Books.

Borowik, I. (2010). Why has religiosity in Poland not changed since 1989? Five hypotheses. Politics and Religion, 3(2), 262-275. 
Borowik, I., Dyczewska, A., \& Litak, E. (2012). Overview of the national situation. In A. Backstrom (Ed.), Welfare and values in Europe: Transitions related to religion, minorities and gender. National overviews and case study reports (Vol. 3, pp. 91-117). Uppsala: Uppsala Religion and Society Research Centre. Davie, G. (2007). The sociology of religion. London: Sage.

Casanova, J. (1994). Public religions in the modern world. Chicago: University of Chicago Press.

Chmielewski, Z., \& Kuca, P. (2013). Polityka informacyjna parafii diecezji rzeszowskiej - raport $\mathrm{z}$ badań [Information policy of the parishes of the Rzeszów Diocese - research report]. Polityka i Społeczeństwo, 3(11), 37-48.

Chmielewski, Z., \& Kuca, P. (2014/2015). Ograniczenia i bariery w komunikowaniu się kapłanów z wiernymi: studium przypadku diecezji rzeszowskiej [Limits and barriers in priests' communication with the faithful: a case study of the Rzeszów Diocese]. Media - Kultura - Społeczeństwo 9/10, 61-69.

Dobbelaere, K. (2002). Secularization: An analysis at three levels. New York: Peter Lang.

Etzioni, A. (2003). Are virtual and democratic communities feasible? Retrieved January 4, 2020 from: https://www.researchgate.net/publication/254927347_Are_Virtual_and_Democratic_Communities_Feasible.

Evolvi, G. (2019). Blogging my religion: Secular, Muslim, and Catholic media spaces in Europe. New York: Routledge.

Guzek, D. (2013). Reklama w działaniach instytucji religijnych w Polsce [Adertising in the activities of religious institutions in Poland]. Chorzowskie Studia Polityczne, 6, 311-326.

Guzek, D. (2019). Mediatizing secular state. Media, religion and politics in contemporary Poland. Berlin: Peter Lang.

Hepp, A. (2019). Deep mediatization. London: Taylor \& Francis Ltd.

Herbert, D. (2015). Theorising religious republicisation in Europe: Religion, media and public controversy in the Netherlands and Poland 2000-2012. In K. Granholm, M. Moberg, \& S. Sjo (Eds.), Religion, Media, and Social Change (pp. 54-70). New York and London: Routledge.

Hjarvard, S. (2008). The mediatization of religion: A theory of the media as agents of religious change. Northern Lights: Film and Media Studies Yearbook, 6(1), 9-26.

Hjarvard, S. (2012). Three forms of mediatized religion. Changing the public face of religion. In S. Hjarvard \& M. Lovheim (Eds.), Mediatization and religion: Nordic perspectives (pp. 21-44). Goteborg: NORDICOM.

Hjarvard, S. (2014). From mediation to mediatization: The institutionalization of new media. In A. Hepp \& F. Krotz (Eds.), Mediatized worlds: Culture and society in a media age (pp. 123-139). New York: Palgrave Macmillan.

Hjelm, T. (2012). Desecularization. In C. R. Wade (Ed.), Encyclopedia of global religion \& society (pp. 293-294). Thousand Oaks: SAGE.

Hjelm, T. (2014). National piety: Religious equality, freedom of religion and national identity in Finnish political discourse. Religion, 44(1), 28-45.

Hjelm, T. (2015). Is God back? Reconsidering the new visibility of religion. In T. Hjelm (Ed.), Is God back? Reconsidering the new visibility of religion (pp. 1-16). London: Bloomsbury.

Hoover, S. M., Schofield Clark, L., \& Rainie, L. (2004). Faith online, Washington, D.C.: Pew Internet \& American Life Project. 
Kołodziejska, M. (2018). Online Catholic communities: Community, authority, and religious individualization. London and New York: Routledge.

Korzystanie z religijnych stron i portali internetowych [Use of religious sites and websites] (2016). Komunikat z Badań CBOS 93, pp. 1-9.

Kościół katolicki w Polsce. Rocznik statystyczny [The Catholic Church in Poland. Statistical yearbook] (2014). Warszawa: Główny Urząd Statystyczny; Instytut Statystyki Kościoła Katolickiego.

Kościót w Polsce. Raport [Church in Poland. Report] (2018). Retrieved March 4, 2019 from: https://drive. google.com/file/d/1XMQWcdiwfldk8ovnxCWCl-OsGjAVZMsU/view.

Kotler, P. (2005). Marketing. Transl. R. Bartołd et al., Poznań: Dom Wydawniczy Rebis.

Kubczak, A., (2005). Konstruowanie tożsamości w Internecie [Constructing identity on the internet]. In E. Hałas \& K. T. Konecki (Eds.), Konstruowanie jaźni i społeczeństwa. Europejskie warianty interakcjonizmu symbolicznego [Constructing self and society. European variants of symbolic interactionism] (pp. 359-377). Warszawa: Wydawnictwo Naukowe „Scholar”.

Künkler, M., Madeley, J., \& Shankar, S. (Eds.). (2018). A secular age beyond the West. Religion, law and multiple secularities in Asia, the Middle East and North Africa. Cambridge: Cambridge University Press.

Luckmann, T. (1967). The invisible religion: The problem of religion in modern society. London: Macmillan.

Lövheim, M. (2011). Mediatisation of religion: A critical appraisal. Culture and Religion, 12(2), 153-166.

Lövheim, M. (2012). Varieties of performing religion in a public sphere. Paper presented at the conference New Forms of Public Religion, 5-7 September 2012. St John's College, Cambridge.

Mariański, J. (2009). Sekularyzacja a nowe formy religijności [Secularization and new forms of religiosity]. Roczniki Nauk Społecznych, 1, 33-68.

Mariański, J. (2010). Praktyki religijne w Polsce - ciągłość i zmiana [Religious practices in Poland continuity and change]. Roczniki Nauk Społecznych, 2, 55-86.

Mariański, J. (2016). Religia i religijność w zsekularyzowanych społeczeństwach [Religion and religiosity in secularized societies]. Zeszyty Naukowe KUL, 59(4), 3-26.

Pawłowska, B. (2015). „Polak-katolik” - czyli o religijności współczesnych Polaków [„Pole-Catholic”, or about the religiosity of contemporary Poles]. Władza Sązenia, 6, 77-92. Retrieved March 4, 2019 from: http://wladzasadzenia.pl/2015/6/polak-katolik-czyli-o-religijnosci-wspolczesnych-polakow.pdf.

Percy, M. (2000). The church in the market place: Advertising and religion in a secular age. Journal of Contemporary Religion, 15(1), 97-119.

Pew Research Center (2018). Eastern and Western Europeans differ on importance of religion, views of minorities, and key social issues. Retrieved March 4, 2019 from: http://www.pewforum.org/2018/10/29/ eastern-and-western-europeans-differ-on-importance-of-religion-views-of-minorities-and-keysocial-issues/.

Religijność Polaków w ostatnich 20 latach [Religion of Poles in the last 20 years] (2020). Komunikat $z$ Badań CBOS, 63, pp. 1-7.

Rocznik Statystyczny Rzeczypospolitej Polskiej [Statistical Yearbook of the Republic of Poland] (2018). Warszawa: Główny Urząd Statystyczny.

Stępniak, K. (2017a). Fenomen reklamy religijnej [The phenomenon of religious advertising]. Warszawa-Pułtusk: Akademia Humanistyczna im. A. Gieysztora. 
Stępniak, K. (2017b). Reklama religijna jako przekaz perswazyjny z elementami sacrum [Religious advertising as a persuasive message with elements of the sacred]. Studia Theologica Varsaviensia, $1,107-129$.

Stępniak, K. (2018). Motywy religijne w komercyjnym przekazie reklamowym a sacrum w przekazie religijnym [Religious motifs in a commercial advertising message and the sacred in a religious message]. Studia Medioznawcze, 2, 85-97.

Szpunar, M. (2005). Internet jako pole poszukiwania i konstruowania własnej tożsamości [The Internet as a field of searching and constructing your own identity]. In E. Hałas \& K. T. Konecki (Eds.), Konstruowanie jaźni i społeczeństwa. Europejskie warianty interakcjonizmu symbolicznego [Constructing self and society. European variants of symbolic interactionism] (pp. 378-403). Warszawa: Wydawnictwo Naukowe „Scholar”.

Szpunar, M. (2010), Reklama dźwignia wiary? Church marketing i jego specyfika [Advertising is a lever of faith? Church marketing and its specificity]. In B. Bednarczyk, Z. Pasek, P. Stawiński (Eds.), Religia a współczesne stosunki międzynarodowe [Religion and contemporary international relations] (pp. 229-247), Kraków: Krakowskie Towarzystwo Edukacyjne - Oficyna Wydawnicza AFM.

Taylor, C. (2007). A secular age. Cambridge, Mass.: Harvard University Press.

Turkle, S. (1995). Life on the screen: Identity in the age of the internet. New York: Simon \& Schuster.

Wellman, B., \& Gulia, M. (1999). Virtual communities as communities: Net surfers don't ride alone. In M. A. Smith, \& P. Kollock (Eds.), Communities in cyberspace (pp. 167-194). London: Routledge.

Zielińska, K. (2009). Spory wokót teorii sekularyzacji [Disputes over the theory of secularization]. Kraków: „Nomos”.

Życie religijne w Polsce. Wyniki Badania spójności społecznej [Religious life in Poland. Results of the social cohesion study] (2018). Warszawa: GUS. Retrieved March 4, 2019 from: https://stat.gov.pl/ obszary-tematyczne/inne-opracowania/wyznania-religijne/zycie-religijne-w-polsce-wyniki-badania-spojnosci-spolecznej-2018,8,1.html. 